\title{
Stressor, Abusive Supervision dan Tipe Kepribadian Terhadap Kelelahan Emosional
}

\author{
Astuti Jovitasari, dan Miftahuddin \\ Fakultas Psikologi Pendidikan UIN Syarif Hidayatullah, Jakarta \\ astutijovi@gmail.com, mifella@yahoo.com
}

\begin{abstract}
The purpose of this study was to see how the influence of stressors from customers, abusive supervision and personality types on emotional fatigue experienced by frontliner employees at the hotel $(N=150)$. Current study used quatitative method. The scale used in this study is Customer-related Social Stressors, Abusive Supervision, Big Five Inventory (BFI).The results of this study indicate that only three independent variables were stated to significantly affect employee emotional exhaustion. Where the three variables are customer expectations that are not appropriate, verbal aggression from customers and abusive supervision.
\end{abstract}

Keywords: Emotional exhaustion, social stressors, abusive supervision, personality

\begin{abstract}
Abstrak
Tujuan penelitian ini adalah untuk melihat bagaimana pengaruh dari stressor dari pelanggan, abusive supervision dan tipe kepribadian terhadap kelelahan emosional yang dialami oleh karyawan frontliner pada hotel $(\mathrm{N}=150)$. Penelitian ini merupakan penelitian kuantitatif. Skala yang digunakan dalam penelitian ini adalah skala Customer-related Social Stressors, Abusive Supervision, Big Five Inventory (BFI). Hasil penelitian ini menunjukkan bahwa hanya tiga variabel independen yang dinyatakan signifikan mempengaruhi kelelahan emosional karyawan.Dimana ketiga variabel tersebut adalah harapan pelanggan yang tidak sesuai, agresi verbal dari pelanggandan abusive supervision.
\end{abstract}

Kata kunci: Kelelahan emosional, social stressor, abusive supervision, tipe kepribadian

\section{Pendahuluan}

Bekerja merupakan aktivitas yang dilakukan individu dalam rangka memenuhi kebutuhan hidupnya.Pekerjaan yang dilakukan individu memiliki karakteristik pekerjaan dan beban kerja yang berbeda-beda.Dalam menjalankan aktivitas pekerjaannya dan memenuhi tuntutan-tuntutan kerja di dalamnya, seorang karyawan dapat mengalami job burnout, khususnya kelelahan emosional.

Menurut Maslach dan Jackson (1981), burnout terdiri dari tiga aspek yaitu yang pertama adalah kelelahan emosional, yang kedua adalah depersonalisasi atau sinisme, dan yang ketiga adalah penurunan prestasi dan motivasi diri.Diantara ketiga aspek tersebut, kelelahan emosional merupakan faktor utama dan mendasar sebagai penentu timbulnya kedua aspek lainnya dari burnout (Maslach \& Jackson, 1981).Dalam penelitian ini yang menjadi fokus utama kajian adalah aspek kelelahan emosional saja karena kelelahan emosional sebagai pencetus timbulnya sindrom burnout (Karatepe \& Uludag, 2008), dengan tujuan jika timbulnya kelelahan emosional dapat dicegah, maka dapat pula mencegah timbulnya burnout.

TAZKIYA (Journal of Psyhology), p-ISSN: 2656-0011, e-ISSN: 2654-7244 
Kelelahan emosional merupakan merupakan keadaan kronis dari penurunan fisik dan emosional yang dihasilkan dari pekerjaan yang berlebihan, tuntutan pribadi dan stres yang berkesinambungan (Wright \& Cropanzano, 1998).Keadaan ini menggambarkan perasaan emosional dan kelelahan kerja yang berat yang dialami seseorang.

Banyak penelitian yang menunjukkan bahwa kelelahan emosional secara signifikan terkait dengan sikap kerja karyawan, yaitu diantaranya Maslach, Schaufeli dan Leiter 2001; Emas 2006; Cole et.al., 2010;. Gemlik, Sisman dan Sigri 2010 (dalam Thanacoodya, Newman \& Fuchs, 2014) mengemukakan bahwa karyawan yang mengalami kondisi kelelahan emosional akan memengaruhi sikap kerja mereka, seperti keinginan untuk berpindah (intention to turnover) dan rendahnya komitmen afektif (affective commitment).

Dampak lainnya dari karyawan yang mengalami kelelahan emosional adalah menurunnya kesejahteraan karyawan (Greenbaum, Quade, Mawritz, Kim \& Crosby, 2014). Sebagaimana dalam penelitian sebelumnya (Maslach \& Jackson 1986; Demerouti, et.al., 2001), dijelaskan bahwa kelelahan emosional sebagai faktor yang berdampak pada kesehatan dan kesejahteraan individu di tempat kerja (dalam Thanacoodya, et.al., 2014) dan berdampak pada hasil pekerjaan seperti kinerja, kepuasan kerja dan intensi turnover (Halbesleben 2010; Hakanen, Bakker \& Jokissari 2011 dalam Thanacoodya, et.al., 2014).

Pada sebuah perusahaan, karyawan frontliner merupakan karyawan yang menjadi barisan terdepan dalam pelayanan pelanggan, kualitas kerja dan pelayanan yang diberikan oleh karyawan frontliner ini dapat menunjukkan bagaimana citra perusahaan tersebut di mata konsumen atau pelanggannya. Jika kualitas kerja dan pelayanan yang diberikan oleh karyawan frontliner ini buruk, maka akan berdampak pula pada buruknya citra perusahaan.

Pada saat ini, persaingan industri telah berkembang menjadi "service-based economy" atau "service oriented" (Grizzle, Zablah, Brown, \& Lee, 2009 dalam Greenbaum, et al., 2014). Karena dalam dunia industri "service oriented" menjadi semakin meningkat (Grizzle, et al., 2009 dalam Greenbaum, Greenbaum, et al., 2014), pelanggan menjadi salah satu stakeholder yang memiliki pengaruh yang cukup besar terhadap keberhasilan suatu perusahaan (Soebandono, 2012). Maka menjadi suatu hal yang penting untuk mengerti dan memahami tantangan-tantangan yang dihadapi oleh karyawan frontliner.

Dalam pekerjaannya yang selalu berhubungan dan berinteraksi langsung dengan pelanggan, tidak semua pelanggan berperilaku positif kepada karyawan, banyak juga perilaku pelanggan yang negatif dan tidak menyenangkan, seperti pelanggan dan menampilkan perilaku kasar atau sikap bermusuhan (Zapf, 2002 dalam Karatepe, Haktanir \& Yorganci, 2010). Kondisi demikianlah yang dikategorikan sebagai customer-related social stressors (Dormann \& Zapf, 2004), yang selanjutnya akan disebut dengan stressor dari pelanggan.

Pada lingkup pekerjaannya, selain berinteraksi dengan pelanggan secara langsung, karyawan frontliner juga bekerja di bawah pengawasan dari seorang supervisor atau atasan yang memiliki karakter dan kepribadian yang berbeda-beda.Ada yang diawasi secara baik dan lembut, tetapi ada juga yang berada di 
bawah pengawasan supervisor yang berkarakter kasar atau agresif, atau yang dikenal dengan abusive supervision.

Abusive supervision menurut Tepper (2000) sebagai persepsi bawahan mengenai bagaimana supervisor atau atasan mereka menampilkan perilaku tidak bersahabat atau bermusuhan baik verbal dan non verbal secara berkelanjutan, tidak termasuk kontak fisik.Penelitian yang dilakukan Tepper (2000); Tsung-Yu dan Changya (2009) dan Chi dan Liang (2013) menemukan bahwa perilaku kasar dari pengawas atau supervisor ditemukan menjadi penyebab utama kelelahan emosional yang dialami oleh para karyawan.

Selain faktor yang berasal dari luar individu, ada faktor personal yang juga turut berperan dalam memengaruhi tingkat kelelahan emosi seseorang, seperti ciri-ciri kepribadian (Maslach et al, 2001; Tokar et al, 1998; Vollrath \& Torgersen, 2000 dalam O'Neill \& Xiao, 2010 ).

O’Neill dan Xiao (2010) mengemukakan bahwa tipe kepribadian neurotisisme digambarkan sebagai sumber utama emosi negatif, seperti kelelahan emosional, karena sifat dasarnya negatif, individu yang tinggi dalam neurotisisme lebih rentan mengalami kelelahan emosional daripada individu dengan neurotisisme rendah.Sementara itu tipe kepribadian ekstraversion cenderung untuk mengalami emosi positif (Costa \& McCrae, 1992 dalam O'Neill \& Xiao, 2010). Dengan demikian, individu dengan ekstraversion yang tinggi cenderung menunjukkan optimisme bahwa segala sesuatunya akan berjalan dengan baik. Karena kecenderungan mereka untuk bersikap optimis tentang masa depan, orang dengan tipe ekstraversion diperkirakan akan mengalami tingkat kelelahan emosional yang lebih rendah.

\section{Kelelahan Emosional}

Maslach dan Jackson (1981) mengatakan kelelahan emosi merupakan kondisi psikologis yang ditandai dengan terkurasnya sumber-sumber emosional, misalnya perasaan frustasi, putus asa, sedih, tidak berdaya, sikap apatis terhadap pekerjaan.Selain itu mereka mudah tersinggung dan mudah marah tanpa alasan yang jelas. Schaufelli dan Enzmann (1998) menjelaskan mengenai antesenden atau kemungkinan penyebab timbulnya kelelahan emosional, yaitu seperti karakteristik biografi (faktor usia, gender, lama bekerja, status pernikahan), karakteristik kepribadian, dan tuntutan pekerjaan.

\section{Stressor dari Pelanggan}

Stressor dari pelanggan menurut Dormann dan Zapf (2004), terdiri dari empat dimensi, yaitu harapan pelanggan yang tidak proporsional (disproportionate customer expectations), agresi verbal pelanggan (customer verbal aggression), pelanggan yang tidak disukai (disliked customers), harapan ambigu pelanggan (ambiguous customer expectations).

Harapan pelanggan yang tidak proposionalmerupakan kondisi dimana pelanggan menunjukan harapan atau keinginan yang tidak proporsional atau tidak sesuai mengenai layanan yang ingin mereka terima dari karyawan.Agresi verbal pelanggan merupakan perilaku agresi secara verbal dari pelanggan, didefinisikan sebagai intensi pelanggan untuk merugikan atau menyakiti karyawan secara verbal.Pelanggan yang tidak disukai merupakan kondisi dimana karyawan diharuskan berhadapan atau berinteraksi dengan pelanggan 
yang bersikap tidak bersahabat, tanpa humor, dan tidak menyenangkan. Harapan ambigu pelanggan merupakan kondisi dimana karyawan harus berhadapan atau menangani harapan atau keinginan pelanggan yang tidak jelas atau ambigu.

\section{AbusiveSupervision}

Abusive supervision menurut Tepper (2000) adalah persepsi bawahan mengenai bagaimana supervisor menampilkan perilaku tidak bersahabat atau bermusuhan baik verbal dan nonverbal secara berkelanjutan, namun tidak termasuk kontak fisik.Menurut Cortina, et al. (2001) dan Neuman dan Keashly (2003 dalam Mitchel \& Ambrose 2012) bahwa dampak dari agresifitas supervisor sebagai sumber utama agresi di tempat kerja yang menimbulkan situasi stres yang dialami oleh karyawan.

Abusive supervision merupakan variabel unidimensional yang tidak memiliki dimensi di dalamnya, bukan merupakan variabel multidimensional. Berdasarkan definisi dari Tepper (2000), indikator abusive supervision terdiri dari dua aspek, yaitu persepsi bawahan mengenai perilaku tidak bersahabat dari supervisor secara verbal dan perilaku tidak bersahabat dari supervisor secara nonverbal, namun kedua aspek tersebut tidak termasuk kontak fisik.Karyawan yang dalam bekerja dibawah pengawasan kasar dari supervisornya (abusive supervision) ini akan cenderung mengalami kepuasan kerja yang rendah dan lebih cenderung mengalami stres kerja dan kelelahan emosional (Tepper, 2000).

\section{Tipe Kepribadian}

Landasan teori tipe kepribadian yang digunakan dalam penelitian ini menggunakan klasifikasi tipe kepribadian Big Five, dimana dua tipe kepribadian yang menjadi variabel dalam penelitian ini yaitu tipe kepribadian ekstraversion dan tipe kepribadian neurotisisme.

Costa dan McCrae (Feist \& Feist, 2010) mendeskripsikan faktor tipe kepribadian ekstraversion, dimana orang dengan skor tinggi pada dimensi ekstraversion cenderung penuh kasih sayang, ceria, senang berbicara, senang berkumpul dan menyenangkan. Sedangkan orang yang memiliki skor tinggi pada neurotisime cenderung penuh kecemasan, tempramental, mengasihani diri sendiri, sangat sadar akan dirinya sendiri, emosional dan rentan terhadap gangguan yang berhubungan dengan stress. Menurut O'Neill dan Xiao (2010), dalam penelitiannya mengatakan bahwa tipe kepribadian ekstraversion berkorelasi negatif dengan kelelahan emosional, sedangkan tipe kepribadian neurotisisme berkorelasi positif dengan kelelahan emosional.

\section{Metode Penelitian}

\section{Partisipan}

Pada penelitian ini, yang menjadi variabel terikat atau variabel dependen adalah kelelahan emosional.Sedangkan yang menjadi variabel bebas atau variabel independen adalah stressor dari pelanggan (customer-related social stressor), abusive supervision dan dua dimensi dari tipe kepribadian Big Five, yaitu tipe kepribadian ekstraversion dan tipe kepribadian neurotisisme.Subjek yang menjadi 
responden dalam penelitian ini adalah karyawan frontliner dari Hotel Cipta, baik Hotel Cipta 1, Hotel Cipta 2 dan juga Hotel Cipta 3, dengan total jumlah responden sebanyak 150 orang.Teknik pengambilan sampel dalam penelitian ini dilakukan secara non probability sampling, yaitu dengan teknik convenience sampling.Dalam penelitian ini, alasan peneliti memilih karyawan frontliner dari Hotel Cipta 1, Hotel Cipta 2 dan Hotel Cipta 3 adalah karena perizinan melakukan penelitian dihotel tersebut mudah diperoleh, dibandingkan hotel berbintang empat atau bintang lima yang tidak memberikan izin untuk melakukan penelitian di hotel tersebut.

\section{Instrumen Pengukuran}

Subjek yang menjadi responden dalam penelitian ini adalah karyawan frontliner dari Hotel Cipta, baik Hotel Cipta 1, Hotel Cipta 2 dan juga Hotel Cipta 3, dengan total jumlah responden sebanyak 150 orang.Teknik pengambilan sampel dalam penelitian ini dilakukan secara non probability sampling, yaitu dengan teknik convenience sampling. Dalam penelitian ini, alasan peneliti memilih karyawan frontliner dari Hotel Cipta 1, Hotel Cipta 2 dan Hotel Cipta 3 adalah karena perizinan melakukan penelitian dihotel tersebut mudah diperoleh, dibandingkan hotel berbintang empat atau bintang lima yang tidak memberikan izin untuk melakukan penelitian di hotel tersebut.

Kelelahan emosional.Peneliti menggunakan skala Maslach Burnout Inventory (MBI) dari Maslach dan Jackson (1981).Alat ukur ini terdiri dari 25 item. Item yang akan digunakan hanyalah sembilan item yang mengukur kelelahan emosional.

Stressor dari pelanggan.Pengukuran untuk variabel stressor dari pelanggan peneliti menggunakan skala customer-related social stressor, yang dikembangkan oleh Dormann dan Zapf (2004) yang terdiri dari 21 item untuk keempat dimensinya, yaitu harapan pelanggan yang tidak proporsional, agresi verbal pelanggan, pelanggan yang tidak disukai, dan harapan ambigu pelanggan.

Abusive supervision.Pengukuran variabel abusive supervision menggunakan Abusive Supervisionltems dari Bennet J. Tepper (2000) sebanyak 15 iem.

Tipe Kepribadian. Instrumen untuk mengukur dimensi dari tipe kepribadian Big Five, yaitu neurotisime dan ekstraversion menggunakan Big Five Inventory yang dikembangkan oleh John dan Pervin (1991). BFI terdiri dari 44 item. Namun karena hanya dua dimensi kepribadian yang digunakan, maka item yang digunakan hanya sebanyak delapan item yang mengukur kepribadian ekstraversion dan delapan item yang mengukur kepribadian neurotisisme dengan total keseluruhan menjadi 16 item yang mengukur tipe kepribadian ini.

\section{Hasil penelitian}

Dalam penelitian ini, peneliti menggunakan teknik analisis regresi berganda (multiple regression analysis).Pertama, peneliti melihat bagaimana besaran R-square untuk mengetahui berapa persen (\%) 
varians dari DV yang dijelaskan oleh IV. Kemudian diperoleh skor R-square sebesar 0,326 atau 32,6\% (Tabel 1). Artinya proporsi varians dari kelelahan emosionalyang dijelaskan oleh semua variabel independen adalah sebesar $32,6 \%$, sedangkan $67,4 \%$ sisanya dipengaruhi oleh variabel lain diluar penelitian ini.

Tabel 1

$R$ Square

\begin{tabular}{ccccc}
\hline Model & $\mathrm{R}$ & $\mathrm{R}$ Square & $\begin{array}{c}\text { Adjusted } \mathrm{R} \\
\text { Square }\end{array}$ & $\begin{array}{c}\text { Std. Error of The } \\
\text { Estimate }\end{array}$ \\
\hline 1 & .571 & .326 & .292 & 7.49883 \\
\hline
\end{tabular}

Dari tabel 2 dapat dilihat hasil uji $\mathrm{F}$ diketahui bahwa sig. $=.000(\mathrm{p}<0.05)$, maka hipotesis nihil yang menyatakan tidak ada pengaruh yang signifikan dari seluruh variabel independen terhadap kelelahan emosionalditolak. Artinya, ada pengaruh yang signifikan dari keempat dimensi dari stressor dari pelanggan (customer-related social stressor), abusive supervision dan tipe kepribadian terhadap kelelahan emosional.

Tabel 2

ANOVA

\begin{tabular}{|c|c|c|c|c|c|}
\hline Model & Sum of Squares & $d f$ & Mean Square & $F$ & Sig. \\
\hline Regression & 3855.875 & 7 & 550.839 & 9.796 & $.000^{\mathrm{a}}$ \\
\hline Residual & 7985.018 & 142 & 56.233 & & \\
\hline Total & 11840.893 & & & & \\
\hline
\end{tabular}

a. Prediktor: (Konstan), Neurotisisme, Ekstraversion, Abusive Supervision, Harapan Pelanggan yang tidak Proporsional, Agresi Verbal Pelanggan, Pelanggan yang Tidak Disukai, Harapan Ambigu Pelanggan.

Selain itu, dalam analisis regresi juga dilihat sumbangan masing-masing variabel independen terhadap variabel dependen, yang disebut dengan proporsi varians.Dari tabel 4 , dapat dilihat proporsi varians atau besar presentasi sumbangan dari masing-masing variabel independen, beserta dengan signifikansinya. 
Tabel 4

Proporsi Varians Masing-Masing Independen Variabel

\begin{tabular}{lcccc}
\hline Variabel & R Square & $\begin{array}{c}\text { R Square } \\
\text { Change }\end{array}$ & $\begin{array}{c}\text { Persentase } \\
\text { Sumbangan }\end{array}$ & Sig. F Change \\
\hline Harapan Pelanggan yang Tidak & .042 & .042 & $4,2 \%$ & $.012^{*}$ \\
Proporsional & .233 & .191 & $19,1 \%$ & $.000^{*}$ \\
Agresi Verbal Pelanggan & .234 & .001 & $0,2 \%$ & .551 \\
Pelanggan yang Tidak Disukai & .241 & .007 & $0,6 \%$ & .282 \\
Harapan Ambigu Pelanggan & .318 & .077 & $7,8 \%$ & $.000^{*}$ \\
Abusive Supervision & .324 & .006 & $0,5 \%$ & .306 \\
Tipe Kepribadian Ekstraversion & .326 & .002 & $0,2 \%$ & .502 \\
Tipe Kepribadian Neurotisisme & & &
\end{tabular}

Berdasarkan hasil analisis multiple regression tersebut, maka kesimpulan yang dapat diambil dari penelitian ini adalah : "Terdapat pengaruh yang signifikan secara keseluruhan dari keempat dimensi dari stressor dari pelanggan, abusive supervision dan tipe kepribadian terhadap kelelahan emosionalpada karyawan frontliner hotel".

Jika dilihat dari signifikan atau tidaknya koefisien regresi dari masing-masing variabel independen, ditemukan bahwa hanya terdapat tiga variabel independen yang menghasilkan koefisien regresi signifikan, yaitu variabel harapan pelanggan yang tidak proporsional (disproportionate customer expectations), agresi verbal pelanggan(customer verbal aggression), dan abusive supervision.Selain daripada itu, variabel independen tersebut juga signifikan sumbangan variannya terhadap kelelahan emosional.Kemudian keempat variabel independen sisanya, yaitu pelanggan yang tidak disukai (disliked customer), harapan ambigu pelanggan (ambigous customer expectations), tipe kepribadian ekstraversion dan tipe kepribadian neurotisisme tidak menghasilkan koefisien regresi dan sumbangan varians yang signifikan terhadap kelelahan emosional pada karyawan.

Dari ketiga variabel independen yang memiliki koefisien regresi dan sumbangan varians yang signifikan, variabel agresi verbal dari pelanggan (customer verbal aggression) yang memberikan sumbangan dengan persentase terbesar, yaitu sebesar 19,1\% terhadap kelelahan emosional.

\section{Diskusi}

Dari hasil penelitian yang telah dilakukan menunjukkan bahwa pengaruh stressor dari pelanggan, abusive supervision, dan tipe kepribadian secara keseluruhan terhadap kelelahan emosionalpada karyawan frontliner hotel, namun hanya tiga dari ketujuh variabel indipenden yang digunakan dalam penelitian ini yang memiliki pengaruh yang signifikan terhadap kelelahan emosional,yaitu harapan pelangganyang tidak proporsional, agresi verbal pelanggan, dan abusive supervision. Kelelahan emosional menurut Maslach dan Jackson (1993 dalam Schaufelli \& Enzmann, 1998 mengacu pada perasaan yang emosional terlalu berat dan terkuras oleh adanya kontak seseorang dengan orang lain. Kelelahan emosional yang dialami individu dapat 
berdampak pada hasil pekerjaan seperti kinerja, kepuasan kerja dan intensi turnover (Halbesleben 2010; Hakanen, Bakker dan Jokissari 2011 dalam Thanacoodya, et.al., 2014).

Harapan pelanggan yang tidak proporsional (disproportionate customer expectations) memiliki pengaruh yang signifikan terhadap kelelahan emosional. Pengaruh variabel independen tersebut bernilai positif, artinya semakin tinggi atau semakin sering karyawan frontliner menghadapi sikap pelanggan yang memiliki harapan yang tidak proporsional (disproportionate customer expectations), maka akan semakin tinggi juga tingkat kelelahan emosional yang ia rasakan. Begitu pula pengaruh dari agresi verbal dari pelanggan memiliki pengaruh yang signifikan terhadap kelelahan emosional. Pengaruh dari variabel tersebut juga bernilai positif, yang artinya juga semakin tinggi atau semakin sering seorang karyawan frontliner menerima agresi verbal pelanggan (customer verbal aggression), maka semakin tinggi pula tingkat kelelahan emosional yang ia alami.

Hasil penelitian yang dilakukan ini konsisten dengan penelitian sebelumnya yang dilakukan oleh Dormann dan Zapf (2004) dan penelitian yang dilakukan oleh Choi, et. al (2014), dimana dalam penelitian tersebut juga menunjukkan bahwa harapan pelanggan yang tidak proporsional dan agresi verbal dari pelanggan menjadi faktor eksternal organisasi yang dapat menimbulkan atau mempengaruhi tingkat kelelahan emosional pada karyawan.

Konsisten dengan hasil penelitian Dormann dan Zapf (2004) dan Choi, et. al., (2014), hasil penelitian ini juga menunjukkan bahwa pengaruh agresi verbal pelanggan terhadap timbulnya kelelahan emosional pada karyawan garis depan menjadi faktor yang memiliki pengaruh paling besar jika dibandingkan dengan ketiga dimensi lainnya dalam variabel customer-related social stressor. Namun, Karatepe et. al., (2010) menemukan bahwa di antara empat komponen customer-related social stressors, hanya harapan ambigu pelanggan (ambigous customer expectations) memiliki dampak positif yang signifikan pada emotional exhaustion. Dengan demikian, hasil penelitian yang dilakukan Karatepe et al. (2010) tidak sama dengan penelitian Dormann dan Zapf (2004), Choi et. al., (2014) dan juga hasil penelitian yang telah peneliti lakukan.

Hal tersebut bisa jadi disebabkan karena adanya perbedaan populasi dari sampel yang digunakan, dimana penelitian yang dilakukan oleh Dormann dan Zapf (2004), dan Choi et. al., (2014) gunakan diambil dari populasi karyawan industri perhotelan atau pariwisata, sedangkan penelitian yang dilakukan oleh Karatepe et. al., (2010) menggunakan sampel dari populasi karyawan frontliner bank. Menurut Karatepe et. al (2010), hubungan yang tidak signifikan antara harapan pelanggan yang tidak proporsional (disproportionate customer expectations), agresi verbal dari pelanggan (customer verbal aggression) dan pelanggan yang tidak disukai (disliked customer) dengan kelelahan emosional dapat dikaitkan dengan fakta bahwa karyawan garis depan pada bank telah diberikan pelatihan khusus untuk menerima perlakuan pelanggan yang demikian. Kemudian ditemukan fakta lain bahwa sampel karyawan garis depan bank bekerja dalam lingkungan di mana memang sudah terdapat prosedur tertulis resmi mengenai interaksi 
keseharian antara karyawan dengan nasabah dan dibekali pengetahuan bagaimana menangani masalah dengan nasabah.

Selain faktor-faktor yang bersumber dari pelanggan sebagai faktor eksternal dari organisasi, yang menyebabkan timbulnya kelelahan emosional pada karyawan, ada juga faktor sikap kasar pengawasan dari atasan atau yang disebut dengan abusive supervision sebagai faktor internal dari organisasi.Hasil penelitian ini membuktikan bahwa abusive supervision memiliki pengaruh yang signifikan terhadap timbulnya kelelahan emosional pada karyawan.Temuan ini konsisten dengan penelitian sebelumnya yang dilakukan oleh Tsung Yu dan Chang Ya (2009) dan juga Chi dan Liang (2013).

Berdasarkan penelitian yang telah dilakukan, peneliti menyadari bahwa masih tersapat banyak kekurangan didalamnya.Untuk itu, peneliti memberikan beberapa saran untuk pertimbangan sebagai penyempurnaan penelitian selanjutnya, baik berupa saran teoritis dan juga saran praktis.

\section{Daftar Pustaka}

Ainsworth, M.D., Blehar, M.C., Waters, E., Wall, S. (1978).Patterns of attachment: A psychological study of the strange situation. Oxford, England: Lawrence Erlbaum.

Angenent, H., de Man AF. (1989). Intelligence, gender, social maturity and school readiness in dutch first graders. Social Behaviour and Personality. 17: 205-209.

Bowlby, J.(1988). Attachment and loss: Vol I Attachment. New York: Basic Books.

Carter, M. (2002). The impact of parent and family involvement of student outcomes: An annotated bibliography of research from the past decade. CADRE.2002-00-00.

Chiccetti,D., \& Carlson. (1989). Child's maltreatment : Theory and research on the causes and concequences of child abuse and neglect.UK : Cambridge University Press.

Cinismo, S.L., Pebley, A., Vaina, M., Maggio, E. (2004).Are L.A's children ready for school ?. Santa Monica: RAND.

Cole, P. (2006). All children ready for school: Heath and physical well being. Early Childhood Center.IN 47408-2696.

Compton, M. (2004).Parent involvement in pre-kindergarten and the effects on student achievement.Thesis, Kansas, US: Wichita State University.

Connel, C.M., \& Prinz, R.J. (2002).The impact of childcare and parent-child interaction on school readiness and social skills development for low-income American children.Journal of School Psychology. 40 (2) pp. 177-193.

Cross, A.F. \& Powers, M.C. (2011).A working paper: New information about school readiness. Bloomington: Indiana University.

DeKlyen, M., Biernbaum, M. A., Speltz, M. L., \& Greenberg, M. T. (1998). Fathers and preschool behavior problems.Developmental Psychology, 34(2), 264-275.

DeMulder, E. K., Denham, S., Schmidt, M., \& Mitchell, J. (2000). Q-sort assessment of attachment security during the preschool years: Links from home to school. Developmental Psychology, $36(2), 274-282$.

Dobbs, J., Doctoroff, G. L., Fisher, P. H., \& Arnold, D. H. (2006). The association between preschool children's socio-emotional functioning and their mathematical skills.Journal of Applied Developmental Psychology, 27(2), 97-108. 
Duncan, G.J., Claessens.A., Huston, A.C., Pagani,L.S., Engel, M., Sexton,H., Dosett, C.J., Magnuson, K., Klebanov,P., Feinstein, L., Brooks-Gunn, J., Duckworth, K. \& Japel, C. (2007). School raediness and later achievement.Journal of Developmental Psychology, 43, 1428-1446.

Epstein, J.L. (2001). School, family, and community partnerships: Preparing educators and improving schools. New York: Corwinpress. ISBN-0-7619-7666-3.

Graue,M.E. (1992). Social interpretation of readiness for kindergarten.Early Childhood Reseach Quarterly. Doi: 10.1016/0885-2006(92)90006-K.

Gredler, G.R. (1992). School readiness: Assesment and educational issues. US:. Willey Press. ISBN0-88422-112-1.

He Ye.(2016). Parental involvement in school readiness programs. HigherEducation of Social Science. Doi: 10.3968/8708.

Huffman, L.C.,Mehlinger,S.L.,\& Kerivan,A.S.(2000). Risk Factors for Academic and Behavioral Problems at The Beginning of School.Chapel Hill. North Carolina: University of North Carolina.

Jacobsen, T., \& Hofmann, V. (1997). Children's attachment representations:

Janus,M. \& Offord, D.R. (2007). Development and psychometric properties of the early development instrument (edi): a measure of children's school readiness. Canadian Journal of Behavioural Science, 39, 1-22.

Janus, M. \& Duku, E. (2007). The school entry gap: socioeconomic, family, and health factors associated with children's school readiness to learn. Early Education and Developent. 18: 375-403.

Krause, K. L., Bochner, S., Duchesne, S. \& McMaugh, A.(2010). Educational psychology (for learning and teaching). Australia: Cencage Learning Australia.

Lara-Cinisomo, Sandraluz. (2004). Are L.A's children ready for school ?.California: Rand Corporation.

Main, M. \& Solomon, J. (1986).Discovery of a new, insecure-disorganized/disoriented attachment pattern.US : Ablex Publishing.

Mendez, L., Mihalas, S., Hardesty, R. (2006).Gender differences in academic development and performances. Washington DC: NAEYC.

Oxford English Dictionary. (2005). England: Oxford University Press.

Piaget, J.(1951). Psychology of intelligence. London: Routledge and Kegan Paul.

Shiller, V.M., Izzard, C.E., Hembree, E.A. (1986).Pattern of emotion expression during separation in the strange situation.Developmental Psychology; 22:378-383.

Van IJzendoorn, M. H., Dijkstra, J., \& Bus, A. G. (1995). Attachment, intelligence, and language: A meta-analysis. Social Development, 4(2), 115-128. 